\title{
ISOLASI DAN SKRINING MIKROBA PENGHASIL BIOSURFAKTAN DARI AIR LAUT YANG TERCEMAR MINYAK
}

\author{
Isolation and Screening of Biosurfactant-producing Microorganisms from \\ Oil-contaminated Sea Water
}

\author{
Ahmad Wibisana ${ }^{1,2}$ \\ 1) Balai Bioteknologi BPPT, Gedung 630 Kawasan Puspiptek Serpong Tangerang Selatan \\ 2) Program Studi Teknik Kimia, Fakultas Teknik, Universitas Pamulang 45363 Pamulang, Tangerang Selatan \\ Email : awibisana2000@gmail.com
}

\begin{abstract}
ABSTRAK
Mikroorganisme penghasil biosurfaktan telah diisolasi dari air laut yang tercemar minyak yang diambil dari beberapa lokasi dermaga di Indonesia. Lima dari 155 isolat yang diisolasi mampu menghasilkan biosurfaktan yang tinggi melalui proses fermentasi menggunakan medium produksi Marine Broth (Difco). Isolat ML4-10 yang diisolasi dari kawasan dermaga kilang minyak Pertamina di Cilacap menunjukkan kemampuan menghasilkan biosurfaktan tertinggi. Pada uji biosurfaktan yang dihasilkan oleh isolat ML4-10 menunjukkan bahwa aktifitas emulsifikasi dan oil displacement, berturut-turut adalah 54,1 \pm 0,8 dan 10,5 \pm 0,3. Biosurfaktan dari ML4-10 juga menunjukkan nilai positif pada uji oil drop test. Pada uji aktifitas emulsifikasi dan oil displacement menggunakan berbagai sumber minyak, biosurfaktan dari ML4-10 juga menunjukkan aktifitas yang tinggi, hal ini menunjukkan biosurfaktan mempunyai potensi aplikasi yang luas.
\end{abstract}

Kata kunci: biosurfaktan, pencemaran minyak, air laut, mikroorganisme, isolat

\begin{abstract}
Biosurfactant-producing microorganisms have been isolated from contaminated sea water, taken from several dock sites in Indonesia. Five of the 155 isolates were able to produce high biosurfactants through a fermentation process using Marine Broth (Difco) as production medium. Isolate ML4-10, isolated from area at Pertamina oil refinery dock in Cilacap, showed the highest ability to produce biosurfactants. The biosurfactant showed high emulsification and oil displacement activity, i.e. $54.1 \pm 0.8$ and $10.5 \pm 0.3$, respectively. Biosurfactant from ML4-10 also showed positive value on oil drop test. In the emulsification and oil displacement activity test using various oil sources, the biosurfactants of ML4-10 also showed high activities, suggesting that biosurfactants has a wide potential application.
\end{abstract}

Keywords: biosurfactants, oil contamination, sea water, microorganism, isolate

\section{PENDAHULUAN}

Biosurfaktan adalah molekul aktif permukaan yang berasal dari sel-sel hidup. Struktur biosurfaktan terdiri dari gugus hidrofilik dan hidrofobik sehingga dapat menurunkan tegangan antarmuka/permukaan.
Berbagai mikroorganisme dapat menghasilkan biosurfaktan, mulai dari kelompok bakteri, kapang, maupun jamur, Biosurfaktan dihasilkan oleh mikroorganisme sebagai produk ekstraseluler ataupun sebagai bagian dari membran sel [1]. Jika dibandingkan dengan surfaktan kimia, maka 
biosurfaktan memiliki banyak keunggulan seperti bersifat biodegradabel, toksisitas rendah, dapat disintesis dari bahan baku yang murah dan terbarukan, stabil pada kondisi $\mathrm{pH}$, suhu maupun kekuatan ionik yang ekstrem [2]. Biosurfaktan juga dapat dihasilkan secara in-situ pada area yang terkontaminasi minyak [3]. Berdasarkan struktur molekulnya, biosurfaktan dapat digolongkan menjadi glikolipida, lipopeptida, kompleks polisakarida-protein, fosfolipida, asam lemak dan lipida netral. Struktur molekul yang variatif tersebut menjadikan biosurfaktan memiliki potensi besar untuk diaplikasikan di berbagai industri, seperti remediasi [4, 5, 6], pertanian [7], deterjen [8], biopestisida [9], kilang minyak [10, 4, 11, 5], biomedik [12], kosmetik [13] dan lain-lain.

Untuk mengisolasi mikroorganisme penghasil biosurfaktan yang potensial untuk aplikasi industri maka perlu dilakukan evaluasi terhadap kemampuan biosurfaktan dalam menurunkan tegangan permukaan. Tegangan permukaan merupakan parameter penting yang menunjukkan keefektifan surfaktan. Salah satu kriteria yang digunakan dalam seleksi biosurfaktan adalah mampu menurunkan tegangan permukaan hingga di bawah $40 \mathrm{mNm}^{-2}$ [14].

Mikroorganisme laut merupakan mempunyai potensi yang besar sebagai penghasil senyawa-senyawa alam, termasuk biosurfaktan. Luas lautan yang meliputi 70\% luas permukaan bumi, merupakan sumber senyawa alam dengan diversitas yang tinggi. Guna mengisolasi mikroorganisme penghasil biosufaktan, area lautan yang tercemar minyak merupakan lokasi yang sangat potensial. Hal ini terkait dengan peran fisiologis biosurfaktan, yaitu dapat mengemulsikan substrat yang tidak larut dalam air melalui penurunan tegangan permukaan, sehingga mikroorganisme dapat menyerap substrat untuk digunakan dalam proses metabolisme, motilitas, sinyal sel, amensalisme, dan lain-lain [15]. Karakteristik biosurfaktan yang unik, seperti struktur gugus hidrofobik maupun gugus hidrofilik, diduga dipengaruhi oleh perbedaan ekologis serta mekanisme persaingan populasi di mikro-habitat [16]. Berdasarkan hal tersebut, maka isolasi mikroba penghasil biosurfaktan dari lingkungan laut yang tercemar minyak menarik untuk diteliti. Biosurfaktan yang diperoleh diharapkan mampu diaplikasi di bidang remediasi, enhanced oil recovery (EOR), pencucian tangki minyak, menurunkan viskositas minyak fraksi berat, stabilisasi emulsi minyak-air dan lainnya. Dalam penelitian ini, dilaporkan isolasi dan skrining bakteri penghasil biosurfaktan yang diisolasi dari air laut yang tercemar minyak dan karakterisasi biosurfaktan terpilih.

\section{BAHAN DAN METODE}

\section{Isolasi Bakteri Penghasil Biosurfaktan}

Sampel air laut yang tercemar minyak diambil dari lima lokasi berbeda yaitu kawasan dermaga nelayan di Manado (kode sampel ML1), kawasan dermaga nelayan di Pelabuhan Ratu Sukabumi (kode sampel ML2), kawasan dermaga nelayan di Muara Karang, Jakarta Utara (kode sampel ML3), kawasan dermaga kilang minyak Pertamina di Cilacap - Jawa Tengah (kode sampel ML4) dan kawasan dermaga Muara Angke Jakarta Utara (kode sampel ML-5). Tumpahan minyak ke laut terjadi sebagai akibat adanya aktifitas bongkar-pasang mesin untuk perbaikan kapal maupun pengoperasian mesin kapal. Sampel diambil menggunakan wadah plastik steril dan disimpan pada $4^{\circ} \mathrm{C}$ hingga digunakan. Isolasi mikroba penghasil biosurfaktan dilakukan dengan metode isolasi langsung. Sampel 
diencerkan secara serial hingga $10^{-5}$ menggunakan $0,85 \%$ air garam steril, dan selanjutnya masing-masing pengenceran diambil sebanyak $100 \mu \mathrm{L}$ dan disebar merata di atas permukaan Nutrient Agar (Difco) dalam cawan petri dan diinkubasi pada suhu $37^{\circ} \mathrm{C}$ selama 48 jam. Bakteri yang tumbuh dengan morfologi berbeda dipilih dan dimurnikan minimum sebanyak 2 kali dengan metode penggoresan kuadran pada media Nutrien Agar (NA), untuk mendapatkan isolat murni. Isolat selanjutnya disimpan dan dipelihara pada NA miring serta digunakan untuk proses skrining bakteri penghasil biosurfaktan.

\section{Skrining Bakteri Penghasil Biosurfaktan}

Kultur segar dari isolat murni yang diinkubasi satu hari sebelumnya disiapkan menggunakan medium NA. Sedikit kultur selanjutnya diambil menggunakan jarum ose dan diinokulasikan ke dalam $5 \mathrm{ml}$ Nutrien Broth (Difco) dan diinkubasi selama 16-20 jam pada suhu $37^{\circ} \mathrm{C}$ dalam water bath shaker dengan kecepatan 180 rpm untuk penyiapan inokulum primer. Sebanyak $2 \mathrm{ml}$ inokulum primer diambil dan diinokulasikan ke dalam $50 \mathrm{ml}$ media produksi yang berisi Marine Broth (Difco) dan selanjutnya ditempatkan di pengocok orbital dengan kecepatan 200 rpm, $30^{\circ} \mathrm{C}$ selama 2 hari.

\section{Uji Aktivitas Biosurfaktan}

Cairan hasil fermentasi disentrifugasi pada 10.000 rpm selama 15 menit untuk memisahkan supernatant dari sel. Supernatan diambil dan digunakan untuk uji aktivitas biosurfaktan. Metode uji biosurfaktan yang digunakan terdiri dari uji aktivitas emulsifikasi, oil displacement test dan drop collapse test

\section{Uji Emulsifikasi}

Uji emulsifikasi digunakan untuk mengetahui kemampuan biosurfaktan dalam mengemulsikan zat cair yang berbeda kepolarannya. Supernatan bebas sel hasil fermentasi dicampur dengan minyak tanah di dalam tabung reaksi (diameter $10 \mathrm{~mm}$, tinggi $20 \mathrm{~cm})$ dengan perbandingan 1:1 $(1,5 \mathrm{ml}$ supernatan dicampur dengan $1,5 \mathrm{ml}$ minyak tanah). Campuran divorteks dengan kecepatan tinggi selama 2 menit dan selanjutnya dibiarkan selama 24 jam sehingga terbentuk emulsi yang stabil. Hasil uji emulsifikasi dinyatakan sebagai indeks emulsifikasi $\left(E_{24}\right)[17,18,19]$.

$$
E_{24}=\frac{\text { tinggi emulsi }}{\text { tinggi total larutan }} \times 100 \%
$$

\section{Oil Spreading Test}

Uji dilakukan dengan menuangkan 50 ml akuades ke dalam cawan petri berdiameter $25 \mathrm{~cm}$. Selanjutnya di atas air tersebut ditetesi $50 \mu 1$ minyak solar sehingga membentuk lapisan tipis minyak di atas air. Di atas lapisan minyak ditetesi $10 \mu \mathrm{l}$ supernatan hasil fermentasi. Jika supernatan mengandung biosurfaktan maka akan terjadi zona bening akibat penyisihan lapisan minyak oleh biosurfaktan. Diameter zona bening yang terbentuk diukur menggunakan jangka sorong. Sebagai pembanding digunakan larutan akuades sebagai kontrol negatif dan SLS 1\% sebagai kontrol positif.

\section{Drop Collapse Test}

Drop collapse test dilakukan sesuai dengan metode Bodour [20] dengan sedikit modifikasi. Uji dilakukan dengan meneteskan $25 \mu \mathrm{l}$ minyak pelumas motor (SAE $20 \mathrm{~W}$ ) pada permukaan parafilm dan didiamkan selama 1 jam agar stabil. Selanjutnya, di atas tetesan minyak ditetesi supernatan bebas sel. Tetesan supernatan di atas minyak akan berbentuk datar jika mengandung biosurfaktan. Sampel yang menghasilkan tetesan berbentuk datar diberi 
skor positif '+' dan tetesan berbentuk bulat diberi nilai negatif '-' [21]. Akuades digunakan sebagai kontrol negatif dan SLS $1 \%$ sebagai kontrol positif.

\section{Karakterisasi Biosurfaktan Terpilih}

Karakterisasi dari biosrfaktan terpilih dilakukan dengan melakukan uji emulsifikasi menggunakan beberapa jenis minyak bumi dan minyak nabati. Jenis minyak bumi yang digunakan adalah minyak pelumas, minyak tanah dan minyak disel, sedangkan jenis minyak nabati adalah minyak kedelai, minyak sawit dan minyak jagung.

\section{HASIL DAN PEMBAHASAN}

Biosurfaktan merupakan molekul yang bersifat amfifilik dengan diversitas yang tinggi, ramah lingkungan dan dapat digunakan secara luas di industri sehingga merupakan bioproduk yang sangat menarik. Guna skrining mikroba penghasil biosurfaktan, isolat murni dikulturkan dalam medium produksi dan pada akhir proses fermentasi, cairan fermentasi disentrifugasi untuk memperoleh supernatan bebas sel. Skrining mikroba didasarkan terhadap kemampuaan mikroba dalam menghasilkan biosurfaktan yang disekresikan ke dalam medium. Dari sudut pandang industri, ekstraseluler biosurfaktan lebih menarik dibandingkan dengan intraseluler biosurfaktan yaitu biosurfaktan yang menempel di dinding sel karena faktor kemudahan dan ekonomi untuk proses rekoverinya [14].

Hasil penelitian ini mengkonfirmasi bahwa area yang tercemar minyak merupakan tempat yang potensial untuk memperoleh mikroorganisme penghasil biosurfaktan. Sebanyak 55 mikroba dengan morfologi yang berbeda dapat diisolasi melalui cara direct plating dari sampel air laut yang tercemar minyak. Sebanyak lima isolat atau 9,1\% dari total isolat menunjukkan kemampuan dalam menghasilkan biosurfaktan.

Uji biosurfaktan dengan metode drop collapse didasarkan pada destabilisasi tetesan cairan oleh surfaktan. Jika tetesan sampel tidak mengandung biosurfaktan maka molekul air yang bersifat polar akan menarik permukaan air dari permukaan hidrofobik minyak sehingga tetesan akan berbentuk bulat dan stabil. Sebaliknya jika sampel mengandung biosurfaktan maka bentuk tetesan akan datar karena tegangan antarmuka antara sampel dan minyak menurun. Diameter tetesan yang terbentuk tergantung dari konsentrasi biosurfaktan dalam sampel yang berkorelasi dengan besarnya tegangan permukaan atau antar muka. Metode ini tidak terlalu sensitif untuk mendeteksi biosurfaktan dengan konsentrasi kecil, namun demikian hasil penelitian menunjukkan bahwa seluruh isolat yang positif pada uji drop collapse juga menunjukkan hasil yang positif pada uji oil displacement dan emulsifikasi. Hal ini menunjukkan bahwa mikroba penghasil biosurfaktan hasil isolasi mempunyai kemampuan yang tinggi dalam menghasilkan biosurfaktan. Dari seluruh isolat penghasil biosurfaktan, isolat ML4-10 mampu menghasilkan biosurfaktan dengan aktifitas emulsifikasi dan oil displacement tertinggi, berturut-turut adalah 54,1 \pm 0,8 dan 10,5 \pm 0,3. Biosurfaktan dari ML4-10 juga menunjukkan bentuk tetesan yang datar pada drop collapse test. Hasil uji biosurfaktan selengkapnya ditampilkan dalam Tabel 1.

Biosurfaktan dari isolate ML4-10 juga menunjukkan kemampuan dalam mengemulsikan berbagai jenis minyak, baik minyak bumi seperti minyak pelumas, minyak tanah, dan minyak disel serta minyak nabati, seperti minyak kedelai, minyak sawit 
Tabel 1. Uji aktifitas biosurfaktan dari mikroba penghasil biosurfaktan yang diisolasi dari air laut yang tercemar minyak

\begin{tabular}{cccc}
\hline $\begin{array}{c}\text { Kode } \\
\text { isolat }\end{array}$ & $\begin{array}{c}\text { Diameter zona bening pada Oil } \\
\text { displacement test }(\mathrm{cm})\end{array}$ & $\begin{array}{c}\text { Indeks emulsifikasi, } \\
\mathrm{E}_{24}(\%)\end{array}$ & $\begin{array}{c}\text { Drop } \\
\text { collapse } \\
\text { test }\end{array}$ \\
\hline ML1-10 & $10,0 \pm 0.5$ & $15,0 \pm 1,7$ & + \\
ML2-01 & $6,9 \pm 1,3$ & $24,4 \pm 0,4$ & + \\
ML2-02 & $5,0 \pm 0,5$ & $10,0 \pm 0.7$ & + \\
ML2-08 & $6,6 \pm 0,3$ & $11,7 \pm 0,7$ & + \\
ML4-10 & $10,5 \pm 0,3$ & $54,1 \pm 0,8$ & + \\
\hline
\end{tabular}

dan minyak jagung. Emulsifikasi Indeks, E24, pada berbagai jenis minyak ditunjukkan pada Tabel 2. Hingga hari ke 5, emulsi menunjukkan sifat yang masih stabil.

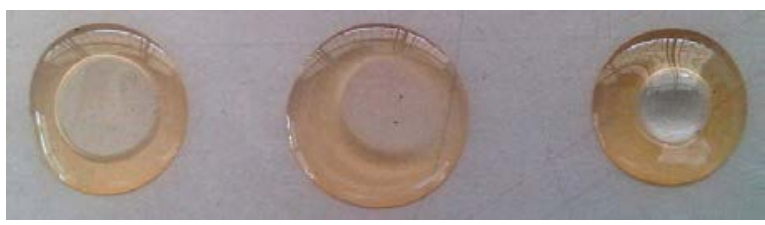

Gambar 1. Uji drop collapse dari (a) kontrol positif: SLS 1\%, (b) biosurfaktan dari isolat ML4-10 dan (c) kontrol negatif: air destilat.

\section{KESIMPULAN}

Lima isolat penghasil biosurfaktan telah diisolasi dari sampel air laut yang tercemar minyak. Biosurfaktan yang dihasilkan mampu mendegradasi berbagai jenis minyak yang ditunjukkan melalui uji aktifitas emulsifikasi dan oil displacement. Biosurfaktan yang diperoleh berpotensi untuk diaplikasikan di berbagai bidang seperti bioremediasi, enhanced oil recovery (EOR), penanganan pencemaran minyak maupun aplikasi di bidang perminyakan lainnya.

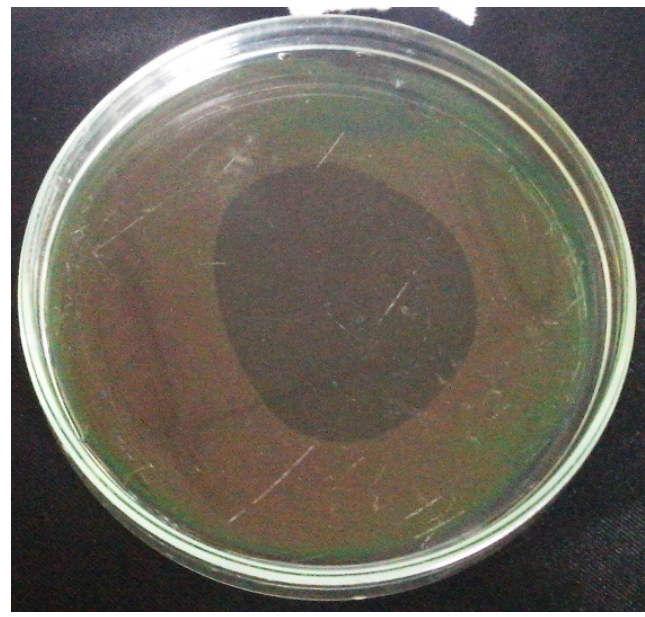

Gambar 2. Uji oil displacement dari biosurfaktan yang dihasilkan oleh isolat ML4-10 


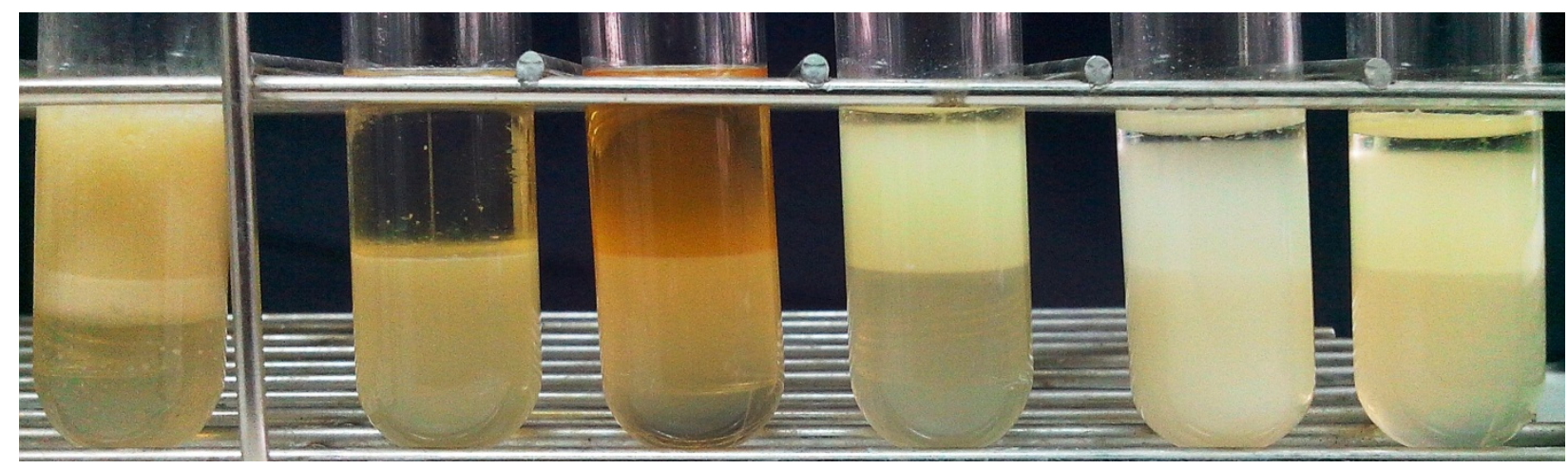

Gambar 3. Uji emulsifikasi dari biosurfaktan yang dihasilkan oleh isolat ML4-10 menggunakan berbagai jenis minyak (a) minyak pelumas, (b) minyak tanah, (c) minyak disel, (d) minyak kedelai, (e) minyak sawit dan (f) minyak jagung.

Tabel 2. Emulsifikasi indeks dan penyisihan minyak dari biosurfaktan dari ML4-10 pada berbagai jebnis minyak

\begin{tabular}{lcc}
\hline Jenis minyak & $\mathrm{E}_{24}(\%)$ & $\begin{array}{c}\text { Diameter zona bening pada } \\
\text { oil displacement test }(\mathrm{cm})\end{array}$ \\
\hline Minyak pelumas & 60,0 & 9,4 \\
Minyak tanah & 54,1 & 9,9 \\
Minyak disel & 40,5 & 8,1 \\
Minyak kedelai & 46,9 & 7,6 \\
Minyak sawit & 88,2 & 8,1 \\
Minyak jagung & 88,2 & 9,3 \\
\hline
\end{tabular}

\section{DAFTAR PUSTAKA}

[1] Satpute S.K., Banat I.M., Dhakephalkar P.K., Banpurkar A.G., Chopade B.A. (2010). Biosurfactants, bioemulsifiers and exopolysaccharides from marine microorganisms. Biotechnol Adv 28(4): 436-450

[2] Fakruddin Md. (2012). Biosurfactant: Production and Application. J Pet Environ Biotechnol. 3:124. doi: 10.4172/2157-7463.1000124.

[3] Cha D.K. (2000). The effect of biosurfactants on the fate and transport of nonpolar organic contaminants in porous media. Environ. Eng., 20: 1-17
[4] Al-Bahry S.N., Al-Wahaibi Y.M., Elshafie A.E., Al-Bemani A.S., Joshi S.J., Al-Makhmari H.S., et al. (2013). Biosurfactant production by Bacillus subtilis B20 using date molasses and its possible application in enhanced oil recovery. Int. Biodeterior. Biodegrad. 81: 141-146. doi: 10.1016/j.ibiod.2012.01.006

[5] Bezza F.A. and Chirwa, E.M.N. (2015). Production and applications of lipopeptide biosurfactant for bioremediation and oil recovery by Bacillus subtilis CN2. Biochem. Eng. J. 101: 168-178. doi: 10.1016/j.bej.2015. 05.007 
[6] Parthipan P., Preetham E., Machuca L.L., Rahman P.K.S.M., Murugan K. and Rajasekar A. (2017). Biosurfactant and Degradative Enzymes Mediated Crude Oil Degradation by Bacterium Bacillus subtilis A1. Front. Microbiol. 8:193. doi: 10.3389/fmicb.2017.00193

[7] Thavasi R., Marchant M. and Banat I.M. (2014) Biosurfactant Applications in Agriculture In book: Biosurfactants, 313-326, DOI: 10.1201/b17599-18

[8] Bouassida M., Fourati N., Ghazala I., Ellouze-Chaabouni S., Ghribi D. (2017) Potential application of Bacillus subtilis SPB1 biosurfactants in laundry detergent formulations: Compatibility study with detergent ingredients and washing performance. Engineering in Life Sciences, doi.org/10.1002/elsc.201700152

[9] Kavitha D., Sureshkumar M., Senthilkumar B. (2016) Screening Of Pesticide Degrading and Biosurfactant Producing Bacteria From Chlorpyrifos Contaminated Soil. Int J Pharm Bio Sci 7(3): 525-532

[10] Amiriyan A., Mazaheri Assadi M., Sajadian V.A., Noohi A.A. (2006) Bioemulsan production by Iranian oil reservoirs microorganism. Iranian $\mathrm{J}$ Env Health Sci Eng. 1: 28-35.

[11] Al-Wahaibi, Y., Joshi, S., Al-Bahry, S., Elshafie, A., Al-Bemani, A., and Shibulal, B. (2014). Biosurfactant production by Bacillus subtilis B30 and its application in enhancing oil recovery. Colloids Surf. B Biointerfaces 114: 324-333. doi: 10.1016/j.colsurfb.2013.09.022

[12] Sharma, D., and Saharan, B.S. 2016. Functional characterization of biomedical potential of biosurfactant produced by Lactobacillus helveticus.
Biotechnol Rep (Amst). 11: 2735. doi: 10.1016/j.btre.2016.05.001

[13] Ferreira A., Vecino X., Ferreira D., Cruz J.M., Moldes A.B., Rodrigues L.R. (2017) Novel cosmetic formulations containing a biosurfactant from Lactobacillus paracasei. Colloids Surf B Biointerfaces. 1(155): 522-529. doi: 10.1016/j.colsurfb.2017.04.026.

[14] Batista, S. B., Mounteer, A. H., Amorim, F. R., and Totola, M. R. (2006) Isolation and characterization of biosurfactant/bioemulsifier-producing bacteria from petroleum contaminated sites. Bioresour. Technol. 97: 868-875. doi: 10.1016/biortech.2005.04.020

[15] Van Hamme J.D., Singh A., Ward O.P. (2006) Physiological aspects part1 in a series of papers devoted to surfactants in microbiology and biotechnology. Biotechnol Adv., 24: 604-620.

[16] Price, N., Rooney, A., Swezey, J., Perry, E., and Cohan, F. (2007) Mass spectrometric analysis of lipopeptides from Bacillus strains isolated from diverse geographical locations. FEMS Microbiol Lett 271: 83-89

[17] Sneha K.S, Padmapriya B. and Rajeswari, T. (2012) Isolation and Screening of Biosurfactants Produced by Pseudomonas aeruginosa from Oil Spilled Soils. International Journal of Pharmaceutical \& Biological Archives 3(2): 321-325

[18] Kalyani A.L.T., Naga Sireesha G., Girija Sankar G., Prabhakar T. (2014) Int. J. Pharm. Sci. Rev. Res., 25(1): 165-170

[19] Peele, K.A., Teja, V.R., Kodali, V.P. (2016) Emulsifying activity of a biosurfactant produced by a marine bacterium. 3 Biotech 6:177, DOI 10.1007/s13205-016-0494-7 
[20] Bodour A.A., Miller-Maier R.M. (1998) Application of a modified dropcollapse technique for surfactant quantification and screening of biosurfactant producing microorganisms. J Microbiol Methods 32: $273-280$.
[21] Youssef N.H., Duncan K.E., Nagle D.P., Savage K.N., Knapp R.M., McInerney M.J. (2004) Comparison of methods to detect biosurfactant production by diverse microorganism. $\mathrm{J}$ Microbiol Methods 56: 339-347. 